\title{
プラズマアクチュエータによる平板列から発生する空力騒音の制御
}

\author{
楠本 誠 ${ }^{* 1}$ ，横山 博史 ${ }^{* 1}$, David ANGLAND ${ }^{* 2}$, 飯田 明由*3
}

\section{Control of aerodynamic noise from cascade of flat plates by plasma actuators}

\author{
Makoto KUSUMOTO $^{* 1}$, Hiroshi YOKOYAMA ${ }^{* 1}$, David ANGLAND ${ }^{* 2}$ and Akiyoshi IIDA*3 \\ ${ }^{{ }^{*},{ }^{* 3}}$ Toyohashi University of Technology Dept. of Mechanical Engineering \\ 1-1 Hibarigaoka, Tempaku-cho, Toyohashi-shi, Aichi 441-8580, Japan \\ ${ }^{* 2}$ Faculty of Engineering and the Environment, University of Southampton \\ Hampshire, SO16 7QF, United Kingdom
}

Received: 19 December 2016; Accepted: 22 February 2017

\begin{abstract}
At specific velocities, intense noise can be generated by the flow around a cascade of flat plates due to acoustic resonance. To reduce the aerodynamic noise, dielectric barrier discharge (DBD) plasma actuators (PAs) were utilized. The aim of this investigation was to clarify the control effects and the mechanism of noise reduction. To do this, wind tunnel experiments and computations were carried out for three vertically aligned flat plates. The PAs were mounted on both sides near the leading-edge of the vertically central flat plate. Moreover, to optimize the deployment of the operated PAs for control, PAs divided in the spanwise direction were utilized, where the PA was composed of 2 parts on each side. Experiments with various combinations of operated PAs were performed. The noise reduction achieved increases as the applied voltage of PAs increases. The maximum reduction of the tonal noise was $10.8 \mathrm{~dB}$ and was achieved by operating the whole array of PAs at a velocity of $13.5 \mathrm{~m} / \mathrm{s}$. The velocity profiles downstream of the PAs changed and the frequency of vortex shedding in the wake of the flat plate decreased with control of the PAs. The velocity corresponding to the maximum acoustic resonance was increased by operating the whole array of PAs. When the array of PAs are partially operated with a spanwise asymmetric deployment, it intensifies the three-dimensionality of the flow. Consequently, the acoustic radiation was weakened with a wider range of frequencies compared to the control by operating the whole array of PAs. The present results indicated that spatial asymmetry deployment is preferred to reduce aerodynamic noise.
\end{abstract}

Key words : Aeroacoustics, Noise control, Cascade of flat plates, Fluid-acoustic interaction, Flow control, Plasma actuator, Acoustic resonance

\section{1. 緒言}

近年，輸送機関の高速化に伴い流れの変動に起因する空力的な騒音が問題となっており，鉄道や航空機，自動 車の設計開発において空力騒音を低減することが重要な課題となっている．空力音は流れ場の非定常な流体運動 や渦の変形に起因して発生し (Howe, 2003)，速度のおよそ4-8 乗に比例して音が増大することが知られている が，騒音低減のための手法が確立されていないため，系統的な対策が行われているとは言い難い状況である.

自動車のフロントグリルには平板を複数枚重ねた平板列が用いられることが多い. このような平板列が流れの 中におかれると，音響フィードバックを伴う強い空力騒音が生じる場合がある. Parker はこのような平板列周り の流れから生じる騒音の計測を行い，特定の流速において音圧レベルが高まることを明らかにした (Parker, 1966, Parker, 1967). さらに，この現象は，平板の後縁から放出される渦の周波数が平板間の音響モ一ドの周波数と一致 することによって生じることを明らかにした，同様な流れと音の連成問題として，East は音響共鳴を伴うキャビ

No.16-00364 [DOI:10.1299/transjsme.16-00364], J-STAGE Advance Publication date: 3 March, 2017

*1 正員, 豊橋技術科学大学大学院 工学研究科（干441-8580 愛知県豊橋市天伯町雲雀ヶ丘 1-1）

*2 Faculty of Engineering and the Environment, University of Southampton (Hampshire, SO16 7QF, United Kingdom)

*3 正員, フェロー，豊橋技術科学大学 機械工学系

E-mail of corresponding author: kusumoto@aero.me.tut.ac.jp 
ティまわりの流れから生じる空力騒音について，キャビティ深さ方向の音響モードと自由せん断層の不安定性が 連成することで音圧レベルが大きくなることが明らかになった (East, 1966). Yokoyama らは Parker や East の研究 をもとに，流れ場を伴う平行平板間における開口端補正の効果を実験から求め，以下に示寸音響共鳴周波数の予 測式を提案した (Yokoyama et al., 2013).

$$
f_{\text {res }}=0.5\left(\frac{a}{C}\right) /\left\{1+\alpha\left(\frac{s}{C}\right)^{\beta}\right\}, \alpha=0.60, \beta=0.89
$$

ここで $\alpha$ と $\beta$ は実験定数である. 平板列から生じる空力騒音は式(1) で示される音響モードの周波数と, 物体か らの渦放出周波数が一致するときに強められる.

さらに，平板列まわりからの発生音に関する流れと音の直接計算の結果から，音響共鳴を伴う条件においては 各平板後縁からスパン方向に軸をもつ二次元的な大規模渦構造が同期して放出され，これにより強いピーク音が 生じることも明らかにされている (Yokoyama et al., 2013). 平板列における音響共鳴を伴う空力騒音が発生するメ カニズムはこれら多くの研究によって解明されつつあるが, こうした空力騒音の制御・低減手法については未だ 確立されたとは言えない，そこで，本研究では，空力騒音を能動的な制御デバイスを用いて低減する手法につい ての検討を行うこととした.

流れ制御デバイスには Vortex generator (Rogers and Parekh, 1994) のように受動的なデバイスをはじめ, Synthetic jet (Amitay et al., 2001) やピエゾアクチュエータ (Yokokawa and Fukunishi, 2001) などのように能動的な流体制御 デバイスがある．特に，流れと音の連成を伴う問題に対して流体制御手法を用いて制御を試みた例として， Yokokawa と Fukunishi はピエゾセラミックアクチュエータをキャビティ上流に設置し，スパン方向に位相を変化 させて駆動することにより, 騒音の低減を達成している (Yokokawa and Fukunishi, 2001).

受動的なデバイスは外部からの動力が不要であるという利点があるが，低減効果が限定的であったり，製品の 外形を変えてしまったりするため, デザイン性の問題などから採用できない場合もある．能動的デバイスは制御 効果が高いが，たとえば，Synthetic jetはドライバユニットをモデル内部に埋め込む必要があることから小型化が 難しく，実際の製品開発に適用寸ることが困難な場合が多い (lida et al., 2008).また，ピエゾアクチュエータは駆 動周波数や振幅などの条件に制約があること，アクチュエータ自体の駆動音が大きいなどの問題がある.

Roth と Dai は誘電体バリア放電による大気圧非平衡プラズマを用いた流体制御手法としてプラズマアクチュエ ータを提案した (Roth and Dai, 2006). プラズマアクチュエータ (以下, PA) は電気的に流れを誘起することがで きるデバイスである. 図 1 にPA の概念図を示す. PA はつの電極とその間の誘電体膜によって構成される. 上 部の電極は空気中に露出しているのに対して下部の電極は誘電体膜によって覆われている．二電極間に高周波高 電圧を印加することで表面プラズマが生じる.このとき電子と正イオンの移動度の違いからプラズマ中は正イオ ンが過剰になりプラズマは非平衡になる. 電極の電位差によって構成される電界との相互作用によってイオンは 静電力を受けて加速され, 中性分子との衝突で運動量が交換され巨視的に電極近傍場で流れが誘起される (Enloe et al., 2004).

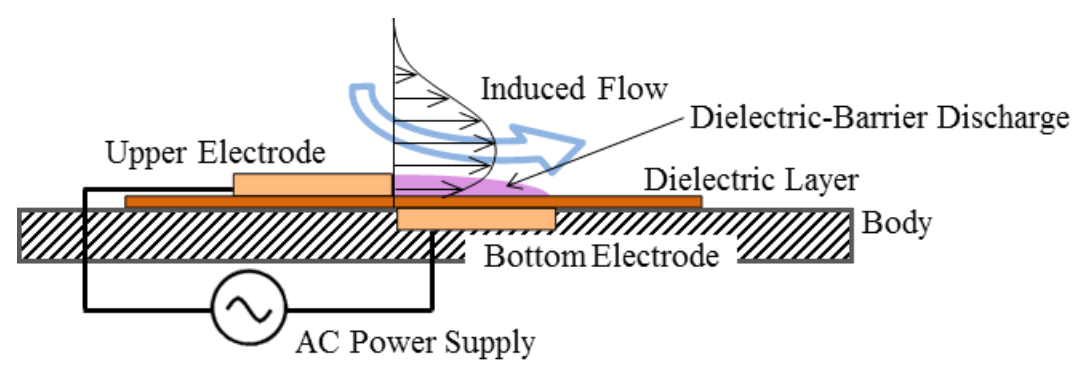

Fig. 1 Configuration of plasma actuator. 
PA は 1) シンプルな構造であり軽量かつ小型で薄い, 2) 機械的可動部などを有せずメンテナンスを必要としな い，3）モデル表面への適用が容易で配置の自由度が高い，4）入力に対する応答性が良好でフィードバック制御 などのアプリケーションに適している，などの特徵がある.

Jukes らは円柱表面にPA を設置し駆動させることで後流のはく離幅の低減や渦放出のタイミングの制御ができ ることを示した (Jukes et al., 2009). さらに, Jukes らは同様にNACA0024 翼の翼負圧面上へPA を設置し，後流 ではく離を伴うような高迎角中においても PA の制御によってはく離を低減させることができることを示した (Jukes et al., 2012). 空力騒音は渦の生成や崩壊，流れのはく離や再付着に密接にかかわっていることから, PA 空力騒音の低減に有用なデバイスであることが予想される. Thomas らは円柱表面に設置した PA を駆動すること で円柱からの渦放出に起因寸る空力騒音を低減した (Thomas et al., 2008). Inasawa らは NACA0012 翼に PA を設 置し，流れと音の連成を伴うフィードバック機構により発生する翼後縁騒音の低減を試みた．特に，設置の影響 を最小限に抑えられるように特殊な構造とした PA を翼面上に装着し, PA 駆動による騒音低減効果の評価を行っ た (Inasawa et al., 2013) .

このように PA は流れ場の制御や空力騒音のデバイスとして注目されており，実際に低減効果が得られること が複数報告されている. 本研究では工業製品の基本形状である平板列に PA を適用し，平板上の流れを制御する ことにより平板列のまわりの流れから放出される音響共鳴を伴う空力騒音の制御効果について調べ, 音響共鳴と 流れ場が連成する条件において PAによる騷音制御のメカニズムを解明することを目的とする．さらに，PAを平 板のスパン方向に分割し, PA の制御面を平板の上下左右で変化させ, PA の駆動条件によって騒音制御効果がど のように変化するかについて調べることにより, 騒音の効果的な低減方法を提案する. 本研究では流速や PA の 駆動条件を変更したパラメトリックスタディから効果的な制御方法を明らかにするため風洞実験を行った. また 制御メカニズムの解明のために, 単独平板に対する PA 制御 (全面駆動) に関して数值解析 (Large Eddy Simulation) を実施することで実験では測定が困難な PA 近傍の流れ場などを取得した.

$\begin{array}{ll}A & : \text { 重み付け変数 } \\ a & : \text { 一様流中の音速 } \\ b & : \text { 平板厚み } \\ C & : \text { 平板コード長 } \\ E & : \text { 電圧 (peak-to-peak) } \\ F & : \text { 体積力 } \\ f & : \text { 周波数 } \\ L_{\mathrm{p}} & : \text { ピーク音の音圧レベル } \\ M=U_{0} / a & : \text { 主流マッハ数 } \\ N & : \text { 平板枚数 } \\ p & : \text { 圧力 }\end{array}$

\section{2. 主な 記 号}

$\begin{array}{ll}R e_{b}=U_{0} b / v & : \text { 平板厚さ } b \text { に基づくレイノルズ数 } \\ s & : \text { 平板間隔 } \\ S t=f b / U_{0} & : \text { 無次元周波数 } \\ t & : \text { 時間 } \\ U_{0} & : \text { 主流速度 } \\ u, v & : x, y \text { 方向の速度 } \\ U_{\mathrm{h}}=\left(u^{2}+(0.5 v)^{2}\right)^{0.5} & : \text { 熱線流速計により測定される流速 } \\ y_{\mathrm{b}}=b / 2 & : \text { 壁面高さ } \\ \Delta & : \text { 格子間隔 } \\ \lambda_{\mathrm{d}} & : \text { デバイ長 } \\ \rho_{0} & : \text { 主流の密度 }\end{array}$

\section{3. 実 験 手 法}

本研究では，低騒音風洞を用いて平板列まわりの流れ場測定および騒音測定を行った．図 2 に実験構成の概略 図を示す．測定部は $3.0 \mathrm{~m} \times 2.5 \mathrm{~m} \times 2.5 \mathrm{~m}$ の無響音室内に配置されている. 壁面を厚さ $300 \mathrm{~mm}$ の吸音材で覆い, 壁面からの音の反射を抑制した。ノズルの $y-z$ 断面は $300 \mathrm{~mm} \times 300 \mathrm{~mm}$ ，測定部長さは $1250 \mathrm{~mm}$ である. 主流速 度 $30 \mathrm{~m} / \mathrm{s}$ における主流の非一様性は $0.5 \%$ 以下，主流乱れは $0.5 \%$ 以下，風洞中心から $1 \mathrm{~m}$ の位置における暗騒 音は $65.2 \mathrm{~dB}(\mathrm{~A})$ である. 実験モデルは, 自動車のフロントグリルを模擬し, 板厚み $b=2.0 \mathrm{~mm}$, コード長 $C=120$ $\mathrm{mm}$ の平板を用い, 単独平板および平板間隔 $s=48 \mathrm{~mm}$ で平板枚数 $N=3$ とした平板列に関して実験を実施した. 平板角部はおよそ R0.2 のフィレット形状とした. 座標原点は平板 (平板列の際は中央平板) の前縁の上下面の中 央とし, 各座標軸は流れ方向を $x$ 方向, 平板の面に垂直な方向を $y$ 方向と定め, 平板スパン方向を $z$ 方向とした. 
騒音測定に使用するマイクロフォンはモデルの中央から主流に対し垂直上方 $430 \mathrm{~mm}(x / b=30.0, y / b=215)$ の 位置に設置した．音圧レベルは精密騒音計を用いて取得した．流れ場の測定には定温型熱線流速計および三軸卜 ラバース装置を用いた．熱線のプローブは I 型を使用し，ワイヤには直径 $5 \mu \mathrm{m}$, 長さ $1.0 \mathrm{~mm}$ のタングステン線 を使用した. 本熱線装置で取得できる物理量は $u_{\mathrm{h}}=\left(u^{2}+(0.5 v)^{2}\right)^{0.5}$ に相当する (Yokoyama et al., 2013). 熱線プロー ブはピトー管を用いて校正を行った。これらの実験は主流速度 $5-30 \mathrm{~m} / \mathrm{s}$ の範囲で実施した.

平板列から生じるピーク音の周波数は主流の速度, 平板の厚み, 前縁形状に依存する. 測定時間内の主流速度 の変化はすべての実験条件において $0.1 \mathrm{~m} / \mathrm{s}$ 未満であることを確認した. 平板の厚みの平板個体差は $2 \%$ 以下であ るが, 平板の配置位置を入れ替えた実験を行った結果, 基本周波数に $1 \%$ 程度の差が生じることを確認した. こ のため，本実験では使用する平板とその配置を変えないで一連の制御実験を行った。制御時と非制御時の比較は 主流速度を一定にしたまま, PA の駆動・非駆動の条件のみを変化させ, 連続して測定を行うことにより実験条件 による差異を抑えた. その結果, ピーク音周波数に与える誤差の影響の程度は $S t=0.001$ (基本周波数の $0.4 \%$ ) 未 満に抑えることができた. これらのことから PA の制御によるピーク音周波数の変化を適切にとらえることがで きると考えられる. 音圧レベルについてはその再現性は同じ平板およびその組み合わせに対して $1 \mathrm{~dB}$ 未満である.

PA は平板列中央の平板の前縁部両面に設置した. PA の $x$ 方向長さは $7 \mathrm{~mm}$ であり, この範囲は $0.25 \leq x / b \leq 3.75$ に相当する. 図 3 にPA の構造を断面の模式図として示寸. 誘電体には厚さ $70 \mu \mathrm{m}$ のポリイミドテープを使用し, 上下二電極には厚さ $80 \mu \mathrm{m}$ の銅簿テープを使用した。一般的に PA の厚みは $0.2-0.3 \mathrm{~mm}$ 程度であり, 図 3 (a) に 示すようにモデルの表面に直接貼り付けて使用される. しかし，本研究の条件では，モデル前縁付近に設置され た PA の厚みは，境界層厚さと比べて十分薄いとはいえず，また，前縁付近の凹凸ははく離に大きな影響を与え ることが予備実験により確認されていることから, 図 3 (b)に示すような埋め込み型の PA (Flush-mounted PA)を作 成した. PAによって流れを誘起する場合, 露出電極が物体表面に突出させることが一般的であり, 露出電極を埋 め込むと効率よく流れを誘起できないと考えられていたが, Inasawa らは物体に電極を埋め込み, 表面をほぼ平 滑にした構造でも一般的な PA と同様に流れが誘起できることを確認している (Inasawa et al., 2013). そこで, 本 研究でも, 流れにさらされる露出電極の段差が最小限となるように作成した. 本実験構成では PA の誘電体表面 と露出電極の段差は $12 \mu \mathrm{m}$ 程度である. 図 4 に PA の設置が基本周波数における音圧レベルに及ぼす影響を調べ た結果を示す. Flush mounted PA を設置した結果は, PA を設置していない結果とほぼ一致し, $U_{0}=14 \mathrm{~m} / \mathrm{s}$ 付近で 音響共鳴が生じ，音圧レベルが急激に上昇することがわかる，一方，従来型の PA を設置した場合共鳴が生じる 速度および音圧レベルが変化することがわかる.

従来型の PA を設置した場合, 前縁でのはく離の状態が変化し, 流れ場および音場が変化している. 本研究で は，PA による誘起流が空力騒音をどのように制御するかについて着目しており，PAの設置が流れ場や音場に影 響を及ぼさないようにする必要があるため Flush mounted PA を用いることとした. Flush mounted PAを設置した 場合の音圧レベルの変化は最大で $3 \mathrm{~dB}$ 程度であった. 図 5 に示寸ように, PA をスパン方向中央で電気的に絶縁 した分割構造とし，スパン方向に独立して駆動させることができるようにした．これにより，駆動する PA の組 み合わせをスパン方向・平板の上下面より, 自由に選択できるようにした．ここで上面の PA を U1, U2, 下面を L1，L2 とする，U1 の背面は L1，U2 の背面には L2 となるように設置した．PA の駆動パターンは全面を駆動し た場合 (U1-U2-L1-L2)，上面の夕駆動した場合 (U1-U2)，下面のみ駆動した場合 (L1-L2)，スパン方向の片側の み駆動した場合 (U1-L1 またはU2-L2)，上下左右を互い違いに位置した場合 (U1-L2 または U2-L1) の 5 パター ンとした．今回使用した PA は，駆動電圧 $E=3.5 \mathrm{kV}$ 程度からスパン方向に一様な放電が得られるため，基本的 に駆動条件は 駆動電圧 $E=4.0 \mathrm{kV}_{\mathrm{p}-\mathrm{p}}$, 駆動周波数 $f=4.0 \mathrm{kHz}$ とした. 本実験に使用する $\mathrm{PA}$ から発生する騒音は 駆動周波数と同じ周波数においてピーク音として発生し, $38 \mathrm{~dB}$ 程度である. 駆動電圧を変化させた場合におけ る最大の駆動電圧条件となる $E=5.1 \mathrm{kV}_{\mathrm{p}-\mathrm{p}}$ において最大 $48 \mathrm{~dB}$ 程度であり, 平板列において共鳴の影響があると 考えられる $13.5-14.0 \mathrm{~m} / \mathrm{s}$ において生じるピーク音圧レベル (60 dB 以上) より十分小さく, 周波数も 3 倍程度異 なり，音響共鳴が生じる流速付近の制御効果に関して評価可能であると考えられる. なお駆動電圧波形は矩形波 とした．表 1 に実験条件一覧を示す. 
Table 1 Experimental and computational conditions.

\begin{tabular}{|c|c|c|c|c|c|c|c|}
\hline & $U_{0}[\mathrm{~m} / \mathrm{s}]$ & $M$ & $R e_{b}$ & $N[-]$ & $b[\mathrm{~mm}]$ & $s[\mathrm{~mm}]$ & $C[\mathrm{~mm}]$ \\
\hline Exp. & $5-30$ & $\begin{array}{c}0.003- \\
0.088\end{array}$ & $\begin{array}{c}6.6 \times 10^{3}- \\
4.0 \times 10^{4}\end{array}$ & 1,3 & \multirow[t]{2}{*}{2.0} & $48($ for $N=3)$ & 30,120 \\
\hline Comp. & 14 & 0.041 & $1.9 \times 10^{3}$ & 1 & & - & 30 \\
\hline
\end{tabular}

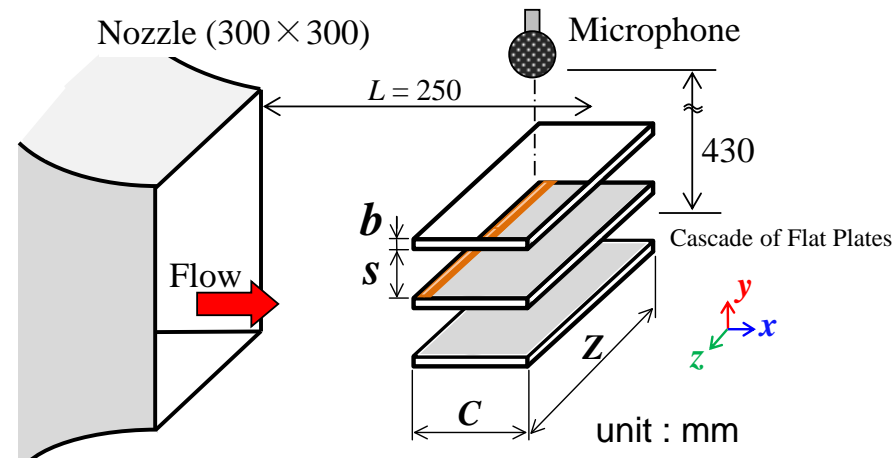

Fig. 2 Schematics for experimental setup.

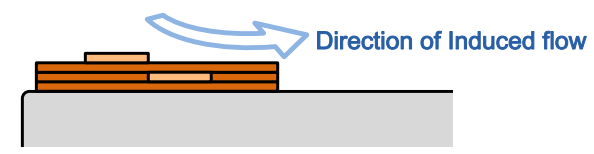

(a) Conventional PA

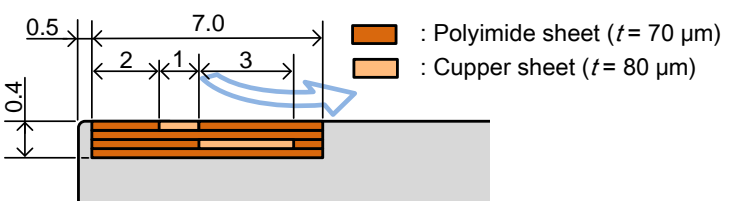

(b) Flush-mounted PA

Fig. 3 Schematics of cross-section of conventional and present flush-mounted PAs.

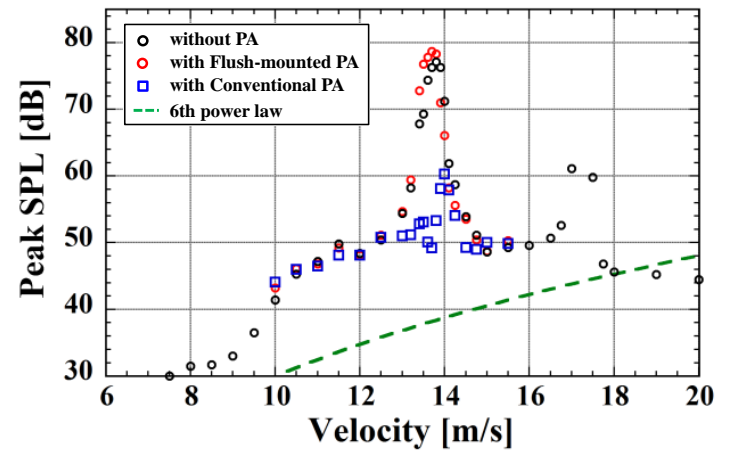

Fig. 4 Comparison of variation of peak SPL along with freestream velocity with flush-mounted and conventional PAs $(E=0 \mathrm{~V})$ and without a PA for cascade $(N=3)$. This figure shows that the effects of flush-mounted PA on the sound pressure are negligibly small.

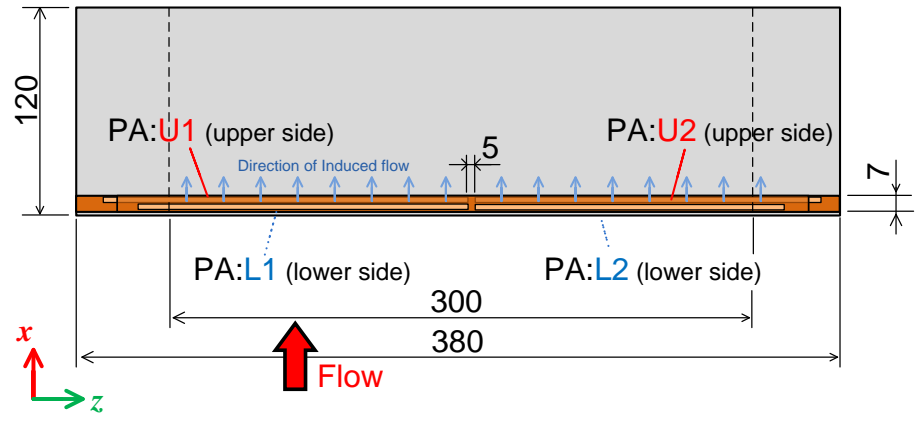

Fig. 5 Schematic of flat plate with plasma actuators (overhead view). The PAs are spanwisely divided into two parts.

\section{4. 計 算 手 法}

\section{$4 \cdot 1$ 対象とした流れ}

単独平板まわりの流れにおけるプラズマアクチュエータ全面駆動制御時 (U1-U2-L1-L2) および非制御時の流 れ場に関して, Large Eddy Simulation (LES) を実施した。解析には FrontFlow/blue を使用した．予備実験により単 独平板の前縁で，流れがはく離再付着し，乱流境界層となること，PAの制御によってはく離が低減すること， これらの特徵的な流れが前縁から $30 \mathrm{~mm}$ までの範囲内で生じていることを確認した. 加えて平板上の流れは単独 平板と平板列の中央の平板で PA 制御時・非制御時ともにほぼ同様の流れとなり，平板列の騒音低減機構は単独 平板における流れの制御機構から説明できることを確認した.これらのことから本解析では計算コストを考慮し, PA の効果を確認するためにコード長 $C=30 \mathrm{~mm}$, 平板厚み $b=2 \mathrm{~mm}$ の単独平板 $(N=1)$ を使用した.

表 1 に計算条件を示す. 主流速度は $U_{0}=14 \mathrm{~m} / \mathrm{s}$ とした. このときのマッ八数は一様流中の音速を $a$ とすると $M$ $=U_{0} / a=0.041$ で, 平板厚みを基準としたレイノルズ数は $R_{b}=\left(U_{0} b\right) / v=1.9 \times 10^{3}$, コード長を基準としたレイノル ズ数は $R e_{C}=\left(U_{0} b\right) / v=2.8 \times 10^{4}$ である. 表 1 に計算条件を示す. 


\section{4-2 LES 解析手法}

支配方程式は以下の式(2)-(4)であり, 空間フィルタにより粗視化された非圧縮性 Navier-Stokes 方程式の右辺項 にPAによる体積力 $F$ を加えたものとした． LES の乱流モデルとして，ダイナミック・スマゴリンスキー・モデ ル (Smagorinsky, 1963, Germano et al., 1991) に Lilly による修正を加えたもの (Lilly, 1992)を使用した.

$$
\begin{aligned}
& \frac{\partial \overline{u_{i}}}{\partial x_{i}}=0 \\
& \frac{\partial \overline{u_{i}}}{\partial t}+\frac{\partial\left(u_{j} u_{i}\right)}{\partial x_{j}}=-\frac{\partial}{\partial x_{j}} \overline{p_{i j}}+F_{i} \\
& \overline{p_{i j}}=\frac{\bar{p}}{\rho_{0}} \delta_{i j}-\overline{\sigma_{i j}}, \overline{\sigma_{i j}}=2 v\left(\overline{S_{i j}}-\frac{1}{3} \frac{\partial \overline{u_{k}}}{\partial x_{k}} \delta_{i j}\right), \overline{S_{i j}}=\frac{1}{2}\left(\frac{\partial \overline{u_{i}}}{\partial x_{j}}+\frac{\partial \overline{u_{j}}}{\partial x_{i}}\right)
\end{aligned}
$$

ここで $i$ は各方向成分， $\rho_{0}$ は流体の密度，vは流体の動粘性係数であり，上付きの-は空間フィルタ（格子フィル タ）により粗視化された值であることを示す.

非定常解析の時間進行法として, Crank-Nicolson 法による陰解法を用い, 圧力解法として Fractional-Step 法 (Kim and Moin, 1985) を用いた．Guo らにより，本計算手法により乱流場が精度よく計算できることが示されている (Guo et al., 2006).

\section{4・3 PAによる体積力}

PA はスパン方向に一様な体積力を与えるものとして, その体積力 $\boldsymbol{F}$ は, Suzen らの手法により, プラズマアク チュエータが空間中に作る電荷分布 $\rho_{\mathrm{c}}$ および電位 $\phi$ を別途計算し, 以下の式(5)で与えた(Suzen et al., 2005). なお, 電荷及び電位の計算に必要となるプラズマのデバイ長 $\lambda_{\mathrm{d}}$ おび空間の最大電荷密度は複数の值を計算し, 実験で 得られた流れ場に最も合うものとし，ここではデバイ長 $\lambda_{\mathrm{d}}=1.4 \mathrm{~mm}$, 最大電荷密度 $\rho_{\mathrm{c}, \max }=0.007 \mathrm{C} / \mathrm{m}^{3}$ とした.

$$
\begin{aligned}
& \boldsymbol{F}=A \rho_{c}(x, y)(-\nabla \phi(x, y)) \sin ^{2}\left(2 \pi f_{\mathrm{PA}} t\right), \\
& A=1(\phi \leq 0), 0.4(\phi>0) .
\end{aligned}
$$

ここで, $f_{\mathrm{PA}}$ はPA の駆動周波数である.さらに, 式(5)における $\sin ^{2}\left(2 \pi f_{\mathrm{pa}} t\right)$ は, Kaneda (2012)らの研究を参考にし, PA の駆動周波数 1 周期中に 2 回放電が起きると仮定した。 また, Forte らのプラズマアクチュエータまわりの流 れ場 (Forte et al., 2007) の Laser Doppler Velocimetry (LDV) 計測結果において, 電圧の正負により誘起される流れ 場に違いが見られたことから, 体積力を電圧の正負で変化させるために式(6)に示寸変数 $A$ を導入した. 变数 $A$ の 值は，別途 Forte らの実験（主流速度 $2 \mathrm{~m} / \mathrm{s}$ における $30 \mathrm{kV}, 700 \mathrm{~Hz}$ で駆動された DBD-PA による誘起流）と体系 を合わせた数值計算を実施し，流れ場を再現するよう設定した．図 6 に予測された流れ場を実験により計測され たものと比較する．平均場や電圧に対する速度の時間変化も精度よく表されていることがわかる.

\section{$4 \cdot 4$ 計算格子}

図 7 に本計算に使用した計算格子の $x-y$ 断面および境界条件を示寸. 格子解像度は平板前縁部からプラズマア クチュエータの露出電極 (厚み $0.006 b$ ) まわりで最も細かく, $\Delta x_{\min } / b=0.002, \Delta y_{\min } / b=0.0015$ となっており，実験 に使用した PA の微小な露出電極の周辺の形状も再現している. 平板後端に向けての流れ方向の格子解像度範囲 は $\Delta x / b \leq 0.085$ であり, スパン方向の解像度は $\Delta z / b=0.056$ である (スパン方向領域広さは $4.5 b$ であり 81 点). 平 板長さに基づくレイノルズ数 $R e_{C}=2.9 \times 10^{4}$ から算出した無次元局所摩擦係数 $c_{\mathrm{f}}=\left(2 \log R e_{\mathrm{C}}-0.65\right)^{-2.3}=0.0078$ 
(Schlichting, 1968) に基づいた wall unit で無次元化すると平板近傍の格子解像度は $\Delta x^{+}=0.24-10, \Delta y_{\min }{ }^{+}=0.19$, $\Delta z^{+} / b=6.7$ となっており，壁面近傍で現れる乱流境界層内の粘性低層および縦渦構造を十分解像できると考えら れる. 格子点数は 6000 万である.

流入境界条件では一様流速度を与え，出口部には対流流出条件を課した．壁面ではす心゙りなし条件，スパン方向 には周期境界条件を課した。
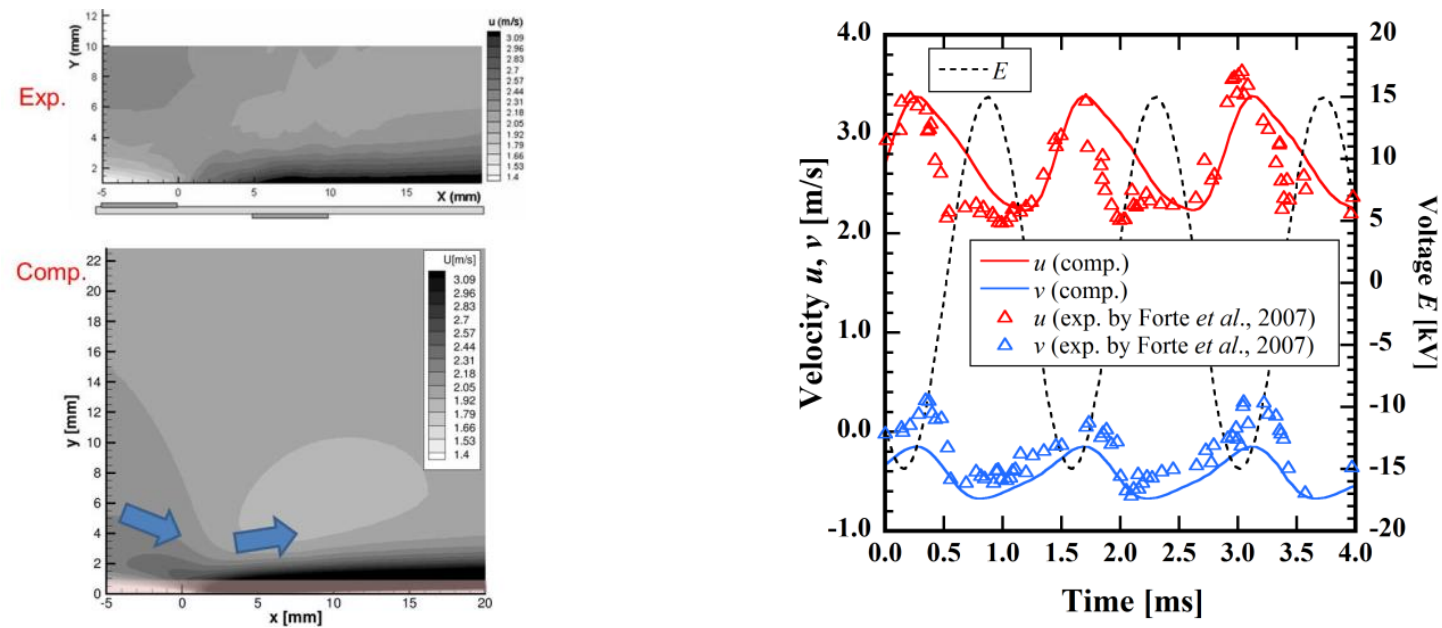

Fig. 6 Measured and predicted contours of mean streamwise velocity $U$ are shown in the left figure, where the measured data are those from the reference (Forte et al., 2007). The right figure shows the time variation of $E, u$ and $v$. This figure shows that the predicted flow fields agree well with those measured.
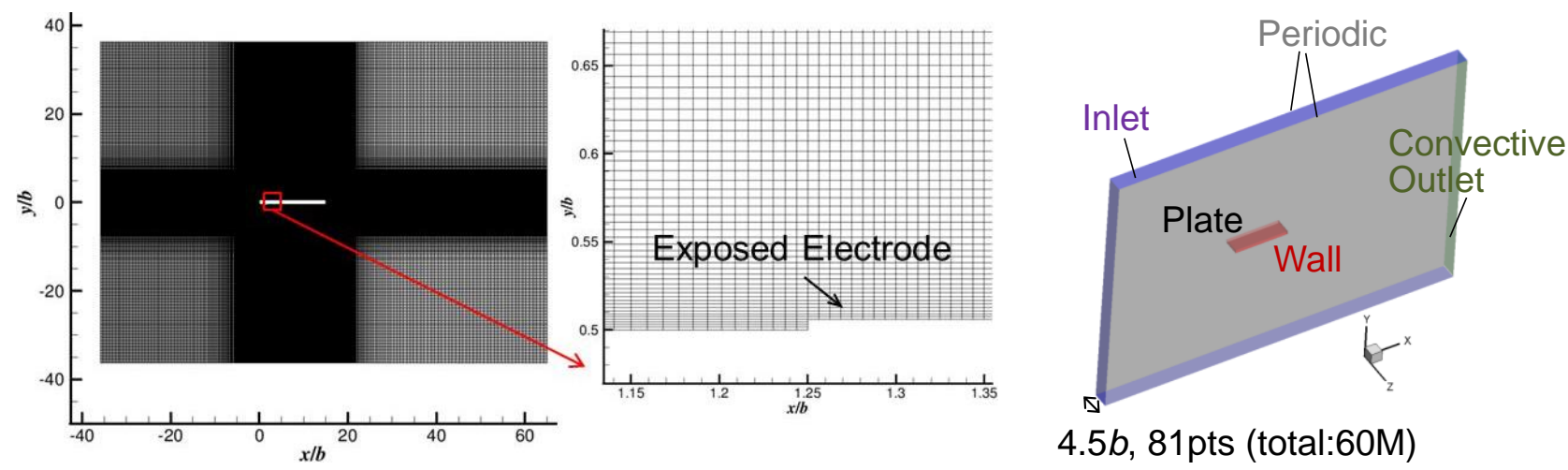

Fig. 7 Computational grid and boundary conditions. Left figure shows all the computational grid. Middle figure show the computational grid near the exposed electrode of plasma actuator. Right figure shows the boundary conditions. Non-slip boundary conditions are used on the wall. The freestream velocity is specified on the inlet conditions. Convective outlet conditions are used on the exit plane.

\section{5. 計 算 手 法 の 検 証}

図 8 に $x / b=4.5$ における単独平板周りの平均速度分布及び乱れ強度を示寸. PA による制御 (上下・スパン方向 全面駆動) を行うことにより，はく離が抑制できることが，実験・解析共に確認することができた．また，PAを 駆動することより, 最大乱れ度が低下寸ることが確認され, 数值解析により PAによる制御効果を評価できるこ とがわかった。これらのPAによる制御機構については次節にて詳しく議論する. 

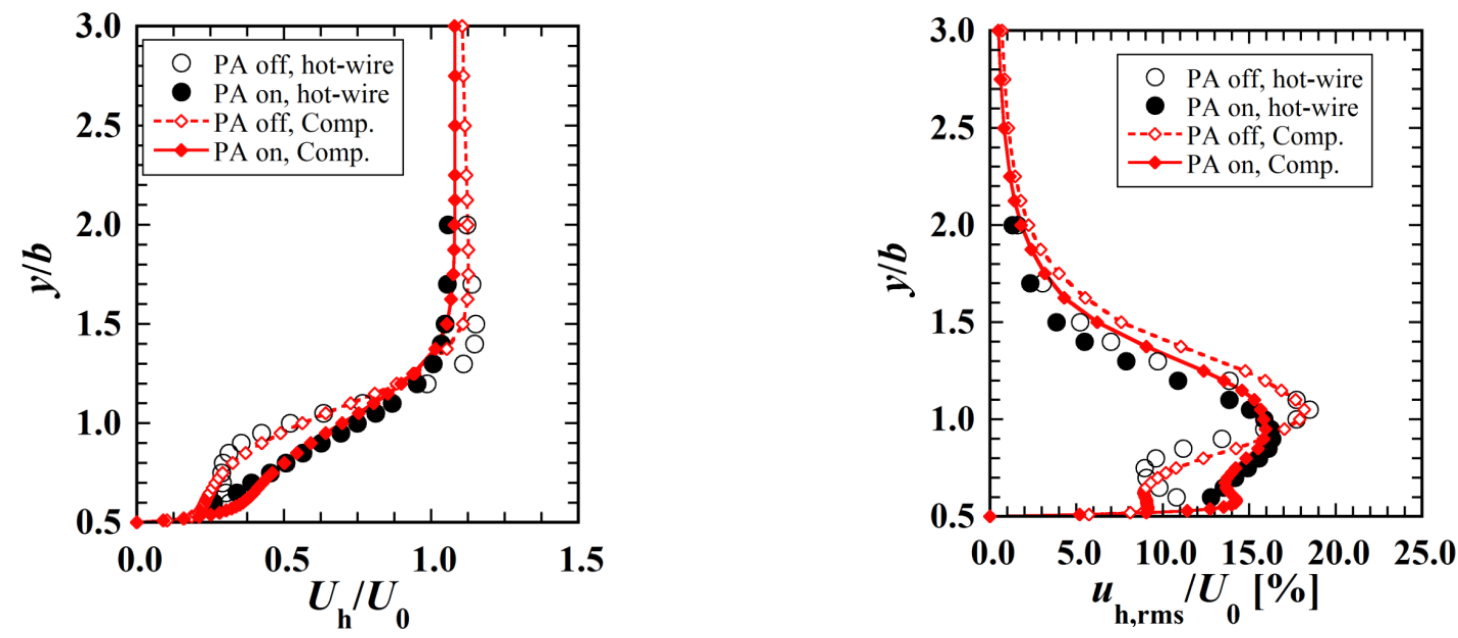

Fig. 8 Measured and predicted profiles of mean streamwise velocity $U_{h}$ at the streamwise position of $x / b=4.5$ are shown in the left figure, where $y / b=0.5$ is corresponding to position of wall. The right figure shows the profiles of turbulent intensity. These figures show both the predicted profiles agree with those measured for the case with and without control by the PA.

\section{6. 結 果}

\section{$6 \cdot 1$ 単独平板および平板列から発生する空力音(非制御時)}

図 9 に単独平板 $(N=1)$, 図 10 に平板列 $(N=3)$ まわりの流れから生じる空力音の周波数スペクトルの主流速 度依存性を示す．周波数解像度は $\Delta f=4.88 \mathrm{~Hz}$ であり，スペクトル平均回数は 582 回である．単独平板，平板列 ともに各流速においてピーク性の騒音が確認できる.これらのピーク音の基本周波数は主流速度 $U_{0}$ の増加に伴い 単調に増加している. 主流速度 $U_{0}$ と平板厚さ $b$ をもとに無次元化したその周波数 $S t$ はおよそ 0.16 から 0.18 であ ることからこのピーク音は平板後流におけるカルマン渦放出に起因するものであると考えられる．ピーク音圧レ ベルは，単独平板では主流速度の増加とともに単調に増加しているが，平板列ではその変化は単調ではない，単 独平板，平板列それぞれのピーク音圧レベルを流速ごとに整理した結果を図 11 に示寸. 単独平板では，ピーク音 圧レベルは流れと音のフィードバック現象が存在することにより主流速度によって音圧レベルは上下するが，お おむ放主流速度の 6 乗に沿っている. しかし平板列では主流速度 $U_{0}=10 \mathrm{~m} / \mathrm{s}$ から $17 \mathrm{~m} / \mathrm{s}$ 付近の流速域でピーク 音圧レベルは 6 乗則に沿わず，およそ $U_{0}=13.8 \mathrm{~m} / \mathrm{s}$ にて極大值をもつことがわかる．このときのピーク音周波数 はおよそ $1180 \mathrm{~Hz}$ である.この流速域では平板のコード長を $1 / 2$ 波長とした音響モードの周波数と，このときの 平板後流からの渦放出周波数が一致することを確認しており，流れと音の連成を伴う音響共鳴によって音圧レベ ルの増加が生じているものと考えられる．また， $U_{0}=17 \mathrm{~m} / \mathrm{s}$ 付近においても極大值が存在し，スパン方向・壁垂 直方向の異なるスケールに対応する高次音響モードとの連成が考えらえるが，本論文では，共鳴によってより音 圧レベルが高まる前述の流れ方向の 1/2 波長モードとの連成について主に議論する.

\section{6 ２ＰA 全面駆動による流れと音の制御機構}

\section{$6 \cdot 2 \cdot 1$ 単独平板における PA 制御}

図 12 にコード長 $C=30 \mathrm{~mm}$ の単独平板からの主流速度 $U_{0}=14 \mathrm{~m} / \mathrm{s}$ の際の発生音のスペクトルに PA 制御が及 ぼす影響の比較を示寸. 4 章で述べたように数值解析における PA の駆動はスパン方向に一様であり, 実験結果の スパン方向・上下全面駆動 (U1-U2-L1-L2) に対応する. 数值解析による音の予測には, Curle の式 (Curle, 1955) を 用いた. 図 12(a)は周波数解像度 $\Delta f=150 \mathrm{~Hz}(\Delta S t=0.02)$, 図 12(b) は $38 \mathrm{~Hz}(\Delta S t=0.005)$ の結果である. $\Delta f=150 \mathrm{~Hz}$ のスペクトルの平均回数は, 計算が 36 回, 実験が 9300 回である. 図 12(a) において, 周波数 $S t<0.15$ の範囲で は実験結果に風洞暗騒音の影響があるため，この範囲においては計算結果と実験結果を直接比較することはでき ないが，実験で観測された $S t=0.2$ 付近における後縁での渦放出に起因寸るピーク音の発生が再現できているこ とがわかる。 


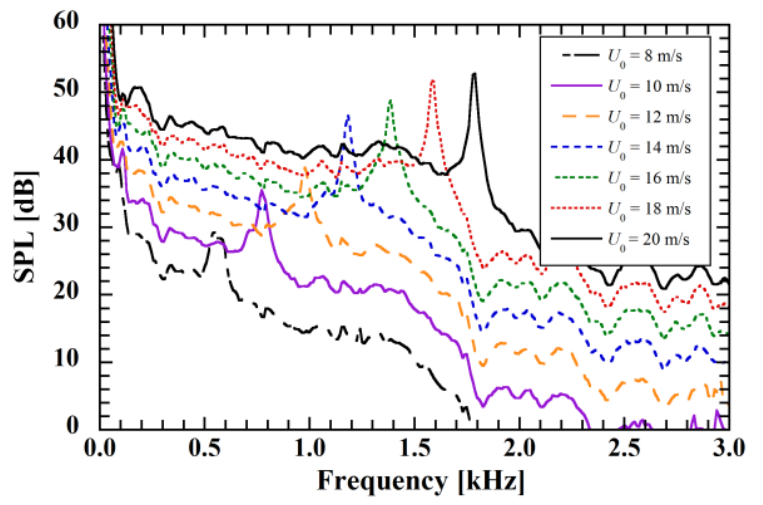

Fig. 9 Spectra of measured aerodynamic noise from flow around the singular plate. Tonal sound at the fundamental frequency is observed for each freestream velocity. The fundamental frequency increase as the freestream velocity increases. Spectra were averaged 582 times for each case. The frequency resolutions are $\Delta f=4.88 \mathrm{~Hz}$.

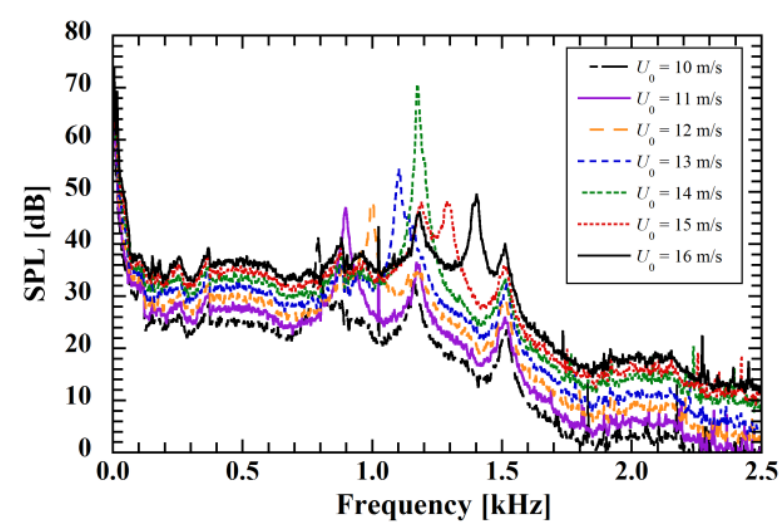

Fig. 10 Spectra of measured aerodynamic noise from flow around cascade of flat plates. Tonal sound at the fundamental frequency is observed for each freestream velocity. This figure shows that the most intense tonal sound radiates at $U_{0}=14 \mathrm{~m} / \mathrm{s}$.

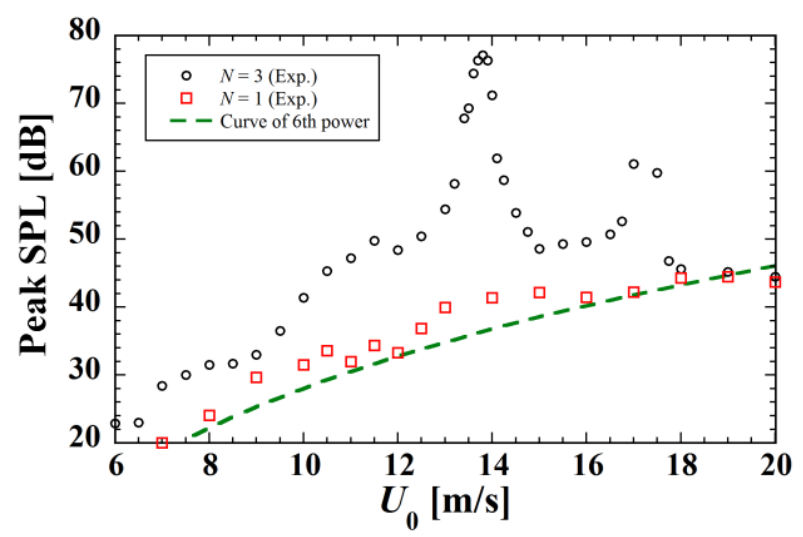

Fig. 11 Variation of SPL at fundamental frequency along with the freestream velocity for flow around cascade of flat plates. The result is conducted by the wind tunnel experiment. Peak sound pressure level increases along with the $6^{\text {th }}$ power of velocity for $N=1$. Local maximal value is observed at $U_{0}=13.8 \mathrm{~m} / \mathrm{s}$ for $N=3$.

さらに，周波数解像度を細かくした図 12(b)より，数值解析においても実験と同様に，PAの駆動によってスぺ クトルのピークが低下する傾向があることが確認できる. 本節の以下では数值計算により明らかになった詳細な 流れ場を用い，基本周波数の低下機構について考察する.

図 13 に PA 制御の有無による平均速度分布の違いを数值解析により比較した結果を示す. 測定位置は $x / b=7.0$, 10.0 と 14.0 である. PA $0.25 \leq x / b \leq 3.75$ の範囲にわたつて設置されているが, PA の直後 $(x / b=7.0)$ では PAに よる誘起流によって境界層内で, 流れが加速されていることが確認できる.このことから平板の前縁で流れはは く離するが, PA の制御によってはく離が抑制されることがわかる. 一方, $x / b=10,14$ では境界層内において流れ が減速していることがわかる.

図 14 にPA 制御の有無による乱れ度の分布の変化を示す.PA制御を行った場合は，境界層内の乱れ度が低下 することがわかる.これは, 前縁のはく離が制御によって弱まり, 渦スケールが小さくなったためと考えらえる. 乱れ度が低下することにより, 主流から壁近くへの運動量の供給が抑えられ, 前述した下流の境界層内の平均速 度の低下が起きたと考えられる.PAによって境界層に運動量を供給し，はく離が抑制される場合，渦スケールが 小さくなり, 渦放出周波数が高くなることが予想されるが, 上記のようにはく離点近傍では境界層が薄くなるが, 後縁付近では境界層が厚くなっている.このようにはく離再付着後の状態が変化し, 平均速度が低下することに より，実験で見られたようにカルマン渦列の渦放出周波数が低くなると考えられる. 




(a) Comparison of measured and predicted spectra.

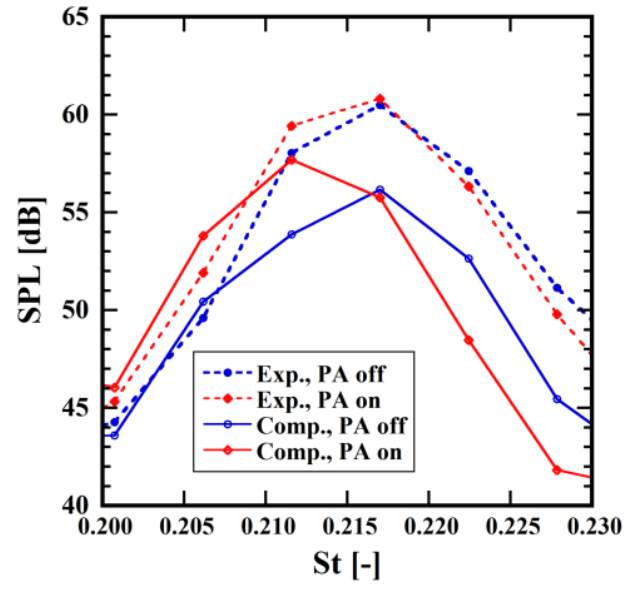

(b) Predicted sound pressure spectra with and without operation.

Fig. 12 Comparison of predicted sound pressure spectra with and without operation of PA. The left figure shows the measured and predicted sound pressure spectra with and without operation of PAs. The predicted pressure spectra agree well with those measured. The right figure shows the predicted sound pressure spectra with and without the operation. The peak is shifted into lower frequency by the operation of PAs in both predicted and measured results.
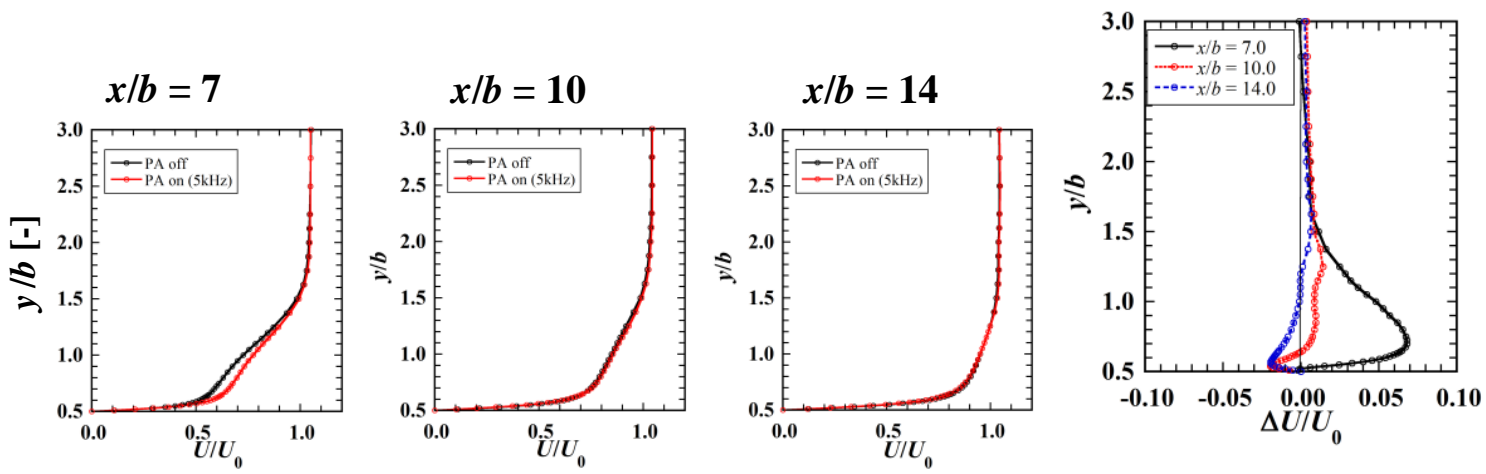

Fig. 13 Predicted mean velocity profiles of $U$ with and without control at $x / b=7.0,10.0$ and 14.0. It is clarified that the velocity is decreased in the boundary layer at $x / b=10.0$ and 14.0 by PAs. Right figure shows the difference between mean velocities with and without the operation of PA.
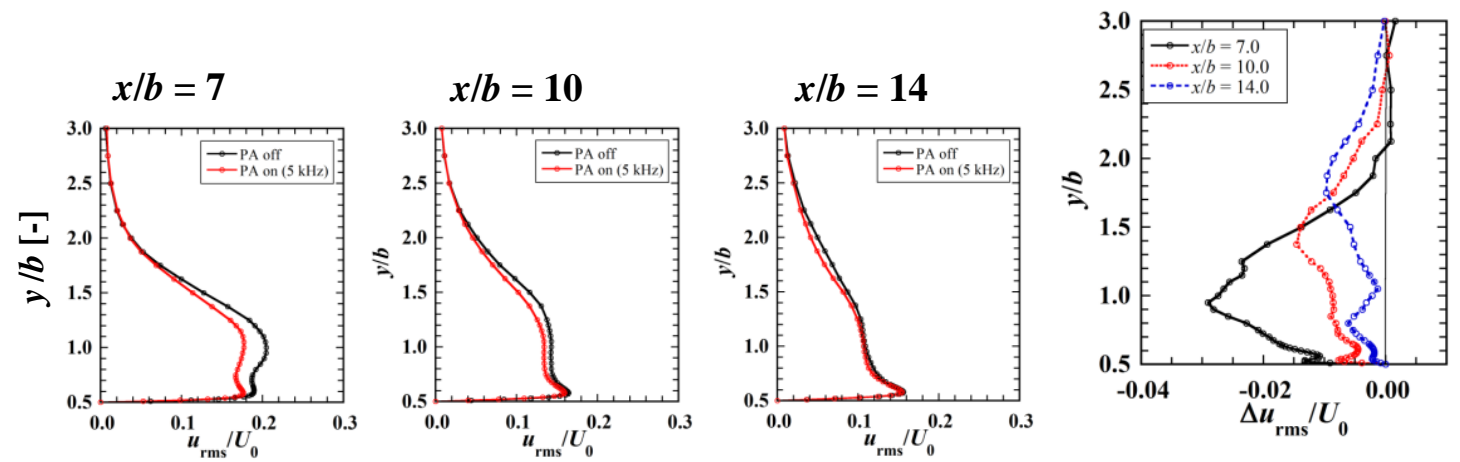

Fig. 14 Predicted profiles of turbulent intensity $u_{\mathrm{rms}}$ with and without control at $x / b=7.0,10.0$ and 14.0. It is clarified that the turbulent intensity is decreased in the boundary by PAs. Right figure shows the difference between turbulent intensities with and without the operation of PA.

\section{$6 \cdot 2 \cdot 2$ 単独平板と平板列の制御効果の比較}

単独平板と平板列においてそれぞれPA をスパン方向・上下全面駆動 (U1-U2-L1-L2) した条件における制御効 果を実験から導いた。なお，以降のデータは実験データによるものであることを付記する．図 15 にPA の制御の 
有無による平板列から生じる騒音のスペクトルの比較を示寸.図 16 に単独平板と平板列におけるピーク音圧レベ ルの主流速度依存性および PA 制御が及ぼす影響を示す。単独平板では，PAの制御によってピーク音圧レベルは 最大で $4 \mathrm{~dB}$ 程度増加していることがわかる. 3 章で述べたように騒音測定の繰り返し再現性は $1 \mathrm{~dB}$ 未満であり, この音圧変化は物理的なものである. 6.1 節で述べたように単独平板においてもフィードバック現象が存在するこ とから PA の制御によって音圧レベルが変化したと考えられるがこの点の詳細については今後の課題である. 平 板列では, 主流速度 $U_{0}=13.2 \mathrm{~m} / \mathrm{s}$ で $6 \mathrm{~dB}$ 程度の低減効果が生じたが, $U_{0}=13.9 \mathrm{~m} / \mathrm{s}$ で $3 \mathrm{~dB}$ 程度の上昇が生じて おり，ピーク音圧レベルの上昇と低下が生じる.

図 17 に単独平板および平板列から生じるピーク音の無次元基本周波数の主流速度依存性およびPA制御が及ぼ 寸影響を示す. 基本周波数は単独平板, 平板列ともに主流速度（レイノルズ数）の増加につれて緩やかに増加す る. 単独平板ではPA を駆動した場合，主流速度 $U_{0}<16 \mathrm{~m} / \mathrm{s}$ の低流速側で基本周波数が低下していることが確認 できる. 平板列の場合, 共鳴点前後の流速域で同様に基本周波数の低下が確認できる. 基本周波数の変化は単独 平板, 平板列ともに最大でも $\Delta S t=0.004$ であるが, 実験における誤差の影響の程度は $S t=0.001$ 未満であること から制御によるこの周波数変化は有意な差であるといえる.この基本周波数の変化は主流速度の変化に置き換え るとおよそ $0.4 \mathrm{~m} / \mathrm{s}$ に相当する. 本研究対象の音響共鳴を生じる平板列においては共鳴点付近で音圧レベルの変化 が大きく, 共鳴点付近では主流速度が $0.4 \mathrm{~m} / \mathrm{s}$ 変化することで音圧レベルは最大で $8 \mathrm{~dB}$ 程度変化するため, この 周波数変化は有意な制御効果といえる. 単独平板を対象とした流れと音の直接計算により, 平板後端からの渦放 出によって音波が発生することが確かめられており, 円柱などと同様に物体後流に形成されるカルマン渦列によ ってピーク音が発生することが知られている (Yokoyama et al., 2013). このことから平板列における PA 制御によ るピーク音圧レベルの制御効果は渦放出周波数の低下によるものと考えられ, 単独平板と平板列の中央の平板で は制御によって同様の現象が起こっていると考えられる. 以下で平板列の中央の平板壁面上の流れ場について詳 しく議論する. なお，図 18 に示すように平板列のピーク音の低減幅は駆動電圧に依存し $E=3.7 \mathrm{kV}$ から $5.1 \mathrm{kV}$ の範囲において駆動電圧の上昇とともに低減効果は単調に増加することを確認した. 本実験条件の最大駆動電圧 である $E=5.1 \mathrm{kV}$ においては, 最大となる $10.8 \mathrm{~dB}$ の低減効果が得られた.

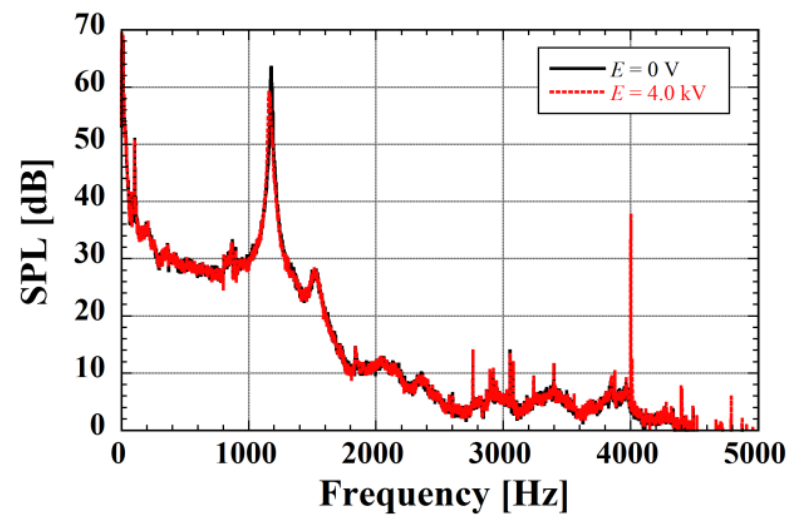

Fig. 15 Comparison of predicted sound pressure spectra with and without operation of whole PAs (U1-U2-L1-L2). The result is conducted by the wind tunnel experiment for cascade $(N=3)$ at $U_{0}=13.2 \mathrm{~m} / \mathrm{s}$. The level decreases with operation.

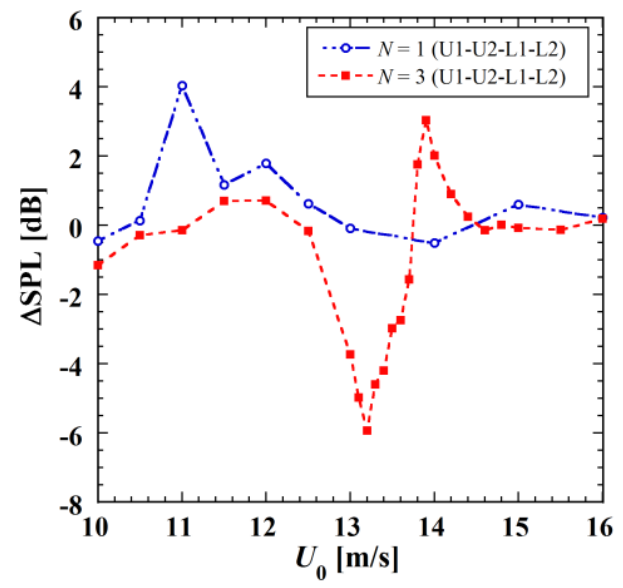

Fig. 16 Comparison of the variations of sound pressure level at fundamental frequency along with the freestream velocity between singular flat plate $(N=1)$ and cascade $(N=3)$. The result is conducted by the wind tunnel experiment with operation of whole sections of PAs (U1-U2-L1-L2). The level increase with operation for $N=1$. On the other hand, increment and decrement are observed at specific velocity range for $N=3$. 


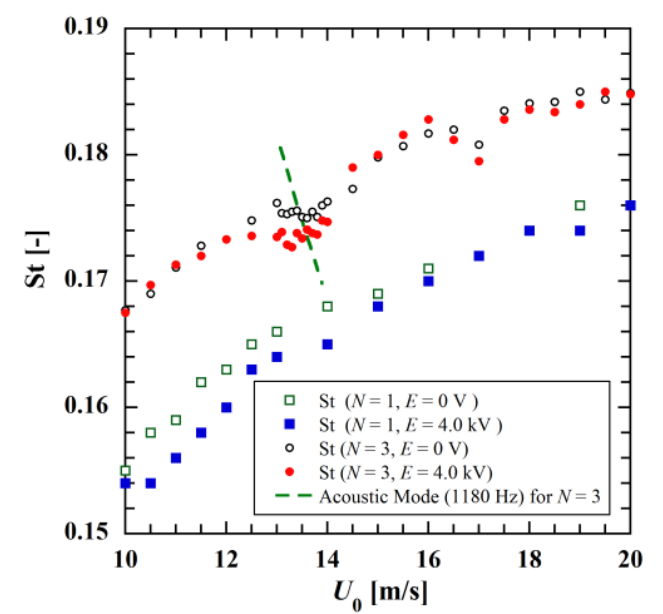

Fig. 17 The variations of fundamental frequency along with freestream velocity with and without operation of PA. The result is conducted by the wind tunnel experiment. The operation was conducted with whole sections of PAs (U1-U2-L1-L2). The fundamental frequency decreases with operation of PAs.

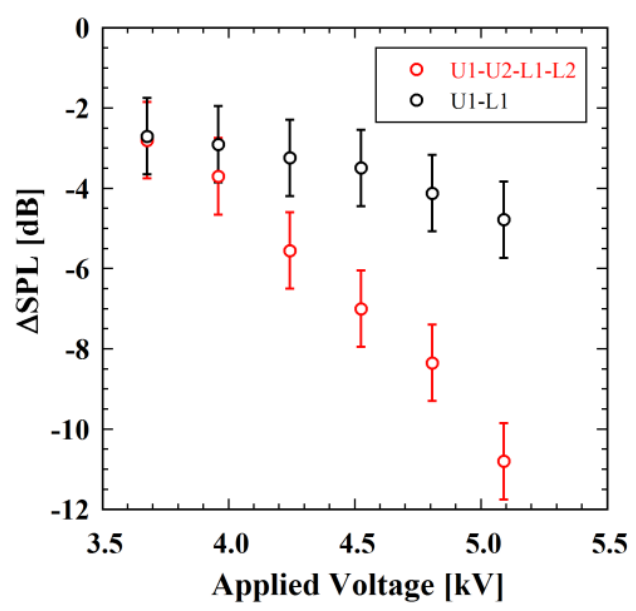

Fig. 18 The effects of applied voltage on measured control effect for flow around cascade of flat plates. The freestream velocity is corresponding to $U_{0}=13.2$ $\mathrm{m} / \mathrm{s}$ for whole sections of PAs (U1-U2-L1-L2) and $U_{0}=13.5 \mathrm{~m} / \mathrm{s}$ for $(\mathrm{U} 1-\mathrm{L} 1)$ where the maximum reduction level was obtained. The operation was conducted with $f=4.0 \mathrm{kHz}$. The reduction level of the tonal noise increases as the applied voltage of PAs increases.

図 19 にPA 制御による騒音低減効果が最大となる主流速度 $U_{0}=13.2 \mathrm{~m} / \mathrm{s}$ における, 平板列中央の平板壁面上 の平均速度分布の変化を示す. 駆動パターンはスパン方向・上下全面駆動 (U1-U2-L1-L2) で, スパン方向中央, 流 れ方向の各点で流れと直角に熱線プローブをトラバースして測定を行った. PA 非駆動の場合, 前節の単独平板の 数值解析結果と同様に, 前縁近傍の $x / b=5.0$ において変曲点型の速度分布となっておりはく離泡の存在が確認で きる. 一方, PA を駆動した場合, 壁面付近の平均速度が増加し速度分布に変曲点がなくなることから流れは壁面 に付着していることがわかる，これはPAの制御によって壁面付近に運動量が供給されたことによるものと考え られる. 下流に向からにつれて，平均速度分布の全体的な差は小さくなるが，壁面近傍の平均速度が低下するの に対して, 壁面から離れた点では, 速度が増加していることが確認できた。これは $6 \cdot 2 \cdot 1$ 節で述べた数值解析 と同様の流れ制御効果である. 図 20 に PA 制御による騒音低減効果が最大となる主流速度 $U_{0}=13.2 \mathrm{~m} / \mathrm{s}$ における 平板後流 $(x / b=62.5, y / b=0.5)$ の速度変動のスペクトルの比較を示寸. 駆動パターンは全面駆動 (U1-U2-L1-L2) である. およそ $S t=0.17$ の周波数で後縁からの渦放出に起因するピークが確認できる. PA を駆動することでこの 渦放出の周波数が 1\%程度低下寸ることがわかる.このことから，全面駆動時 (U1-U2-L1-L2) では渦放出周波数 が低下するため，平板間の音響モードと渦放出周波数が一致する流速が高流速側にずれることにより，非駆動時 に音響共鳴が発生した流速では，共鳴が発生しなくなり，音圧レベルが低下寸ると考えられる．このため，主流 速度が高くなると再び共鳴周波数と渦放出周波数が一致し，ピーク音が発生する．このことから全面駆動による PA 制御では, 音の発生機構を本質的に変えているのではなく, 共鳴が発生する流速条件を変えているため, 主流 の速度によってピーク音の増大と減少が生じる。このことからこのような制御を実際の製品に適用する際は, 非 制御時に共鳴音が発生する条件でのみ PA 制御を行うことが効果的であり, 主流速度によって PA の制御・非制御 を切り替える必要がある. 


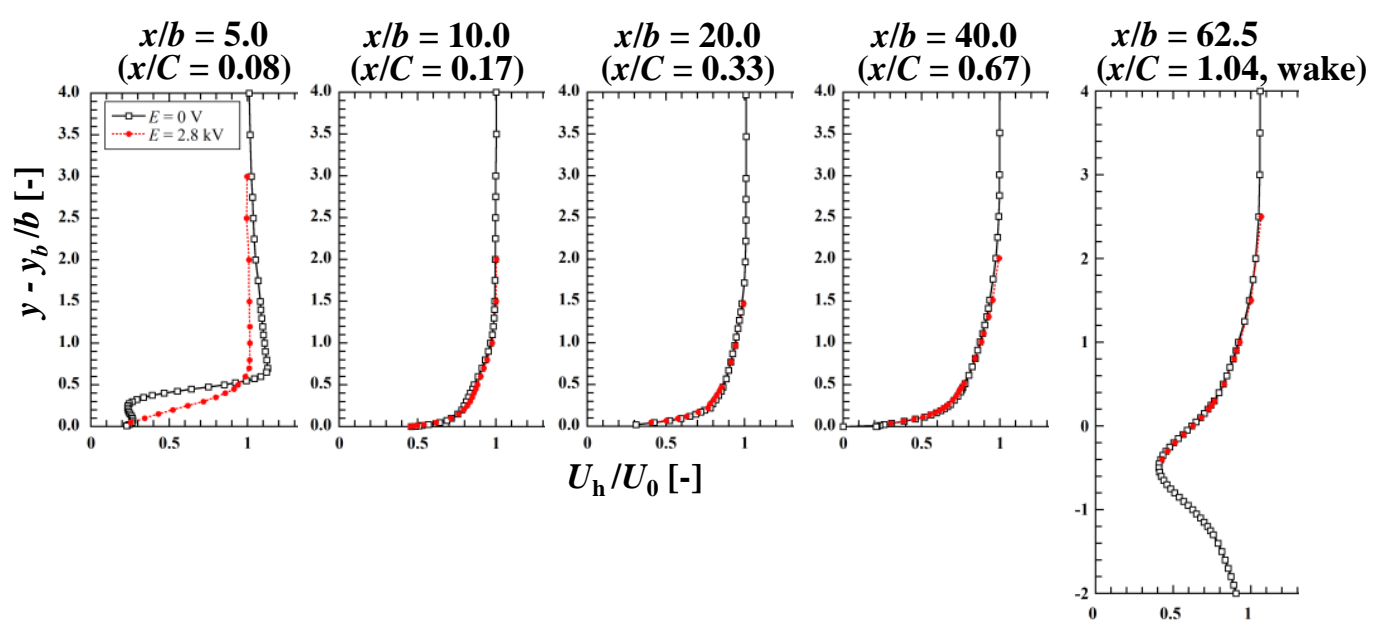

Fig. 19 Comparison of mean velocity profiles on the center plate with and without operation of PAs measured by experiment at $U_{0}$ $=13.2 \mathrm{~m} / \mathrm{s}$. The operation was conducted with whole sections of PAs (U1-U2-L1-L2). The figure of $x / C=0.08$ shows that the separation is suppressed by the operation of PAs.

\section{6・2-3 スパン方向に非一様な PA 駆動による平板列共鳴音の制御}

平板列において PA をスパン方向に非一様な駆動パターンとした条件における制御効果を実験から導いた．図 21 に各 PA 駆動パターンにおける放出音のスペクトルの比較を示す.すべての駆動パターンで騒音低減効果が得 られた主流速度 $U_{0}=13.5 \mathrm{~m} / \mathrm{s}$ で測定を行った. 全面駆動および片面だけを駆動した駆動条件 (U1-U2), (L1-L2) で はピークが分裂しバイモーダルとなることがわかった。これは，本研究では中央の平板のみを PA 制御している ため，中央の平板と外側の平板で異なる周波数の音が発生しているためと考えられる．また，スパン方向に非一 様な駆動 (U1-L1), (U1-L2)ではピーク周波数は PA 非駆動時と同じであり，ピーク音圧レベルそのものが低減し ていることがわかった。図 22 に PA 制御によるピーク音圧制御効果の主流速度依存性を示す. PA を部分的に駆 動させた場合には，音圧レベルが増加する主流速度はなく，非共鳴時においても空力音が抑制できることがわか る. 非制御時に音響共鳴周波数と渦放出周波数が一致し，ピーク音圧レベルが大幅に増加する主流速度付近で最 も効果的に音圧レベルを抑制できることも確認できた. 図 18 に PA を部分的に駆動させた場合における騒音低減 効果の駆動電圧依存性を示す. 全面駆動時と同様に，駆動電圧が上昇するにつれて単調に低減効果が増大するこ とがわかった.

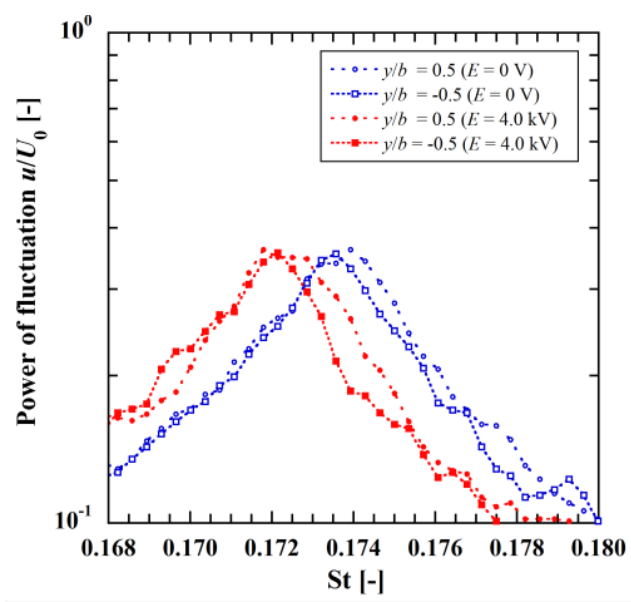

Fig. 20 Spectra of measured velocity fluctuations in the wake of central flat plate $(x / b=62.5, y / b= \pm 0.5)$ with and without operation for cascade of flat plates of $N=3$ at $U_{0}=13.2 \mathrm{~m} / \mathrm{s}$. The operation was conducted with whole sections of PAs (U1-U2-L1-L2). The frequency of vortex shedding in the wake of central flat plate is decreased when PAs are operated. 


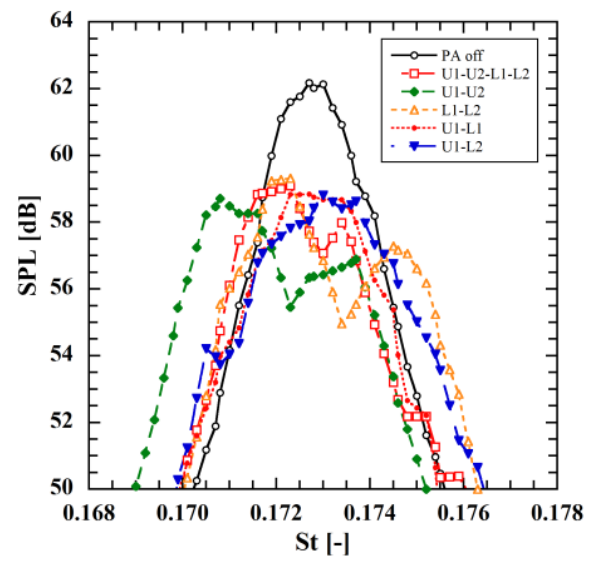

Fig. 21 Spectra of measured sound pressure by different operation patterns of PAs compared with that without operation for cascade of flat plates of $N=3$ at $U_{0}=13.5 \mathrm{~m} / \mathrm{s}$. The peak is separated into two peaks for (U1-U2-L1-L2), (U1-U2) and (L1-L2), while the tonal sound is decreased without change of fundamental frequency for (U1-L1) and (U1-L2).

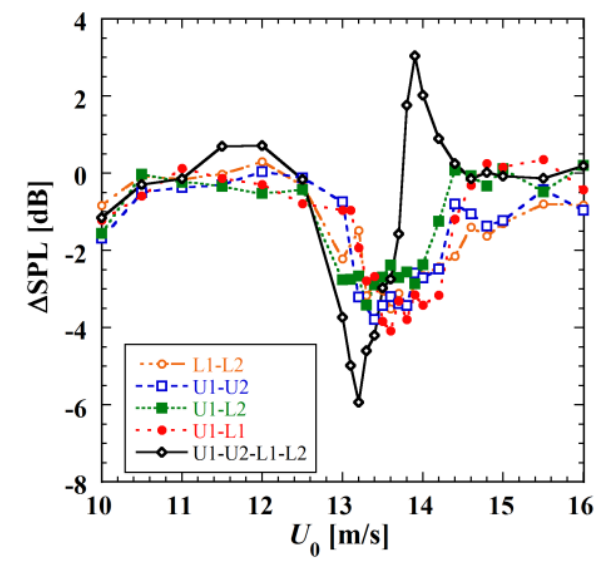

Fig. 22 Comparison of control effect of measured tonal sound by different operation patterns of PAs for flow around cascade of flat plates. The tonal sound is suppressed when partial PAs are operated. The operation was conducted with $E=4.0 \mathrm{kV}$ and $f=$ $4.0 \mathrm{kHz}$.

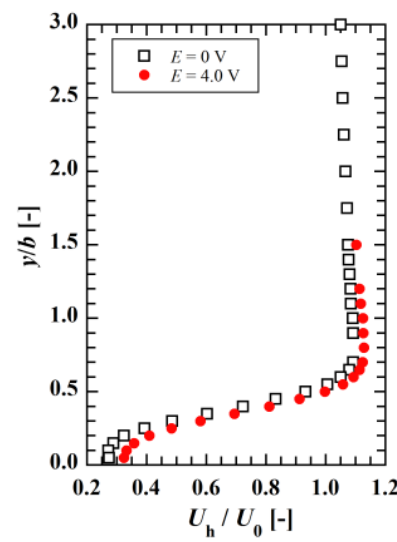

(a) $z / b=37.5$ (in the downstream of operated PA)

(b) $z / b=-37.5$ (in the downstream of not operated PA)

Fig. 23 Measured Mean velocity profiles $U_{\mathrm{h}}$ at $U_{0}=13.5 \mathrm{~m} / \mathrm{s}$ with and without control at $x / b=5.0$, where only one-sided PAs are operated (U1-L1). This figure shows that the separation is suppressed only in the downstream of operated PAs.

図 23 に，スパン方向に非対称な駆動パターン (U1-L1) による平板壁面上での平均速度分布 $(x / b=5.0, z / b=$ 土37.5) の変化を示す. 効果的な騒音低減効果が得られた主流速度 $U_{0}=13.5 \mathrm{~m} / \mathrm{s}$ で測定を行った. 壁面近傍での平 均速度分布は上流の PA が駆動されているスパン方向区間のみ運動量が供給されることによりはく離が抑制され ていることを確認した. このため，平板スパン方向の渦構造が三次元化すると考えられる. カルマン渦に代表さ るスパン方向に強い二次元性を持った渦は，空力音を発生させやすい．スパン方向に非対称な制御を行うと，平 板前縁付近で発生する渦構造を三次元化することができるため, 非共鳴時におけるカルマン渦による空力音を抑 制することができる，全面駆動の場合，非共鳴時の渦構造を三次元化する効果が得られないため，非共鳴時の音 を抑制することができなかったが，非対称制御の場合は，騒音を抑制することが可能であることがわかる．音響 共鳴が生じる条件では，平板前縁において音響学的フィードバックの効果により，前縁の渦の二次元性は非常に 強くなる. この二次元的な渦が渦構造を維持したまま下流に対流し, 後縁付近でスパン方向にコヒーレントな渦 音源を形成し，強い音を発生させることが明らかになっている (Yokoyama et al., 2013).

スパン方向に非対称な制御を行った場合，前縁から放出される渦構造を三次元的にするとともに，平板上の渦 構造の対流速度をスパン方向に変化させることにより, 後縁付近の渦構造が非制御時に比べて,三次元的となり， 放射音が小さくなる，後縁で発生する空力音が小さくなることにより，音波によって前縁の渦を二次元化する効 果も小さくなるため, 渦 (音源) の強度も小さくなり, 結果的に発生する空力音が小さくなるものと考えられる. 
非対称駆動では，渦放出周波数を変化させて騒音を制御した全面駆動とは異なり，フィードバック機構そのもの を制御していることがわかる．これらのことから PA による空力音制御においては非対称駆動などの渦構造を考 慮した制御が重要であることがわかった。

\section{7. 結 言}

平板列から発生する空力騒音を低減し，そのメカニズムを明らかにすることを目的として，流れに与える影響 を最小限に抑える構造としたプラズマアクチュエータ (Flush-mounted PA) を単独平板および平板列の中央平板 の前縁に設置し，騒音制御実験とこれに対応する数值解析を行い，以下の知見を得た.

1.PA を Flush-mounted とすることで流れ場および放出音に与える影響を比較的小さく保ちながらモデル表面 への設置が可能であり, 平板列からの音響共鳴を伴うピーク性の空力騷音の PA の駆動による制御効果を明らか にすることができた．

2. 非制御時には平板の前縁近傍では流れがはく離するが, 前縁のPA を駆動することで境界層内の壁面近傍 に運動量を供給しこのはく離は抑制される. スパン方向・上下全面駆動 (U1-U2-L1-L2) した場合, スパン方向に 一様な流れの変化によって後縁からのカルマン渦列の渦放出周波数およびピーク音の周波数は低下寸る.これに より音響共鳴の効果でピーク音圧レベルが高まる $U_{0}=13.0 \mathrm{~m} / \mathrm{s}-14.0 \mathrm{~m} / \mathrm{s}$ 付近で, 共鳴が最大となる主流速度がよ り高流速側に変化することによってピーク音圧レベルの上昇と低下が生じる.

3.PA を平板の上下片面の夕駆動させることで放出音のスペクトルのピークは二つにわかれ，ピーク音圧レベ ルは共鳴点付近の広い速度域で低下寸る. 一方, スパン方向片側面のみ PA を駆動させた条件では, 平板上で PA が駆動されているスパン方向区間のみ運動量が供給されることではく離が低減され，速度分布がスパン方向に非 一様となり，ピーク音圧レベルは共鳴点付近の広い速度域で低下寸る。これは, 平板前縁において音響学的フィ ードバックにより発生した渦構造がスパン方向に位相が変わり後縁付近の渦構造が非制御時に比べて, 三次元的 となり，発生音のスパン方向の強め合いが弱まったためと考えらえる．これらのことから流れと音の連成を伴う 空力騒音の制御にはスパン方向に非一様な制御が有効であると考えられる.

\section{References}

Amitay, M., Smith, D. R., Kibens, V., Parekh, D. E. and Glezer, A., Aerodynamic flow control over an unconvenstional airfoil using synthetic jet actuators, AIAA Journal Vol.39 (2001), pp.361-370.

Curle, N., The influence of solid boundaries upon aerodynamic sound, Proceedings of the Royal Society, Series A, Vol.231 (1955), pp. 504-514.

East, L. F., Aerodynamically induced resonance in rectangular cavities, Journal of Sound and Vibration, Vol. 3, No. 3 (1966), pp.277-287.

Enloe, C. L., McLaughlin, T. E., VanDyken, R. D., Kachner, K. D., Jumper, E. J. and Corke, T. C., Mechanisms and responses of a single dielectric barrier plasma actuator: Plasma morphology, AIAA Journal, Vol. 42, No.3 (2004), pp. 589-594.

Forte, M., Jolibois, J., Pons, J., Moreau, E., Touchard, G. and Cazalens, Optimization of a dielectric barrier discharge actuator by stationary and non-stationary measurements of the induced flow velocity: Application to airflow control, Experiments in Fluids, Vol.43, No.6 (2007), pp.917-928.

Germano, M., Piomelli, U., Moin, P. and Cabot, W. H., A dynamic subgrid-scale eddy viscosity model, Physics of Fluids, A, Vol.3, No.7 (1991), pp.1760-1765.

Gerrard, J. H., Measurements of the sound from circular cylinders in an air stream, Proceedings of the Physical Society London, Section B Vol.68 (1955), pp.453-461.

Guo, Y., Kato, C. and Yamade, Y., Basic features of the fluid dynamics simulation software FrontFlow/Blue, SEISAN KENKYU, Vol.58, No.1 (2006), pp.11-15.

Howe, M. S., Theory of vortex sound (2003), pp.25-39, Cambridge Press. 
Huang, X. and Zhang, Z., Streamwise and spanwise plasma actuators for flow-induced cavity noise control, Physics of Fluids Vol.20, No.3 (2008), pp.037101-1-037101-10.

Iida, A., Honda. T., Oguma, N. and Kato, C., Active control of feedback noise from a small step on the surface of rear-view mirror, Review of Automobile Engineering (2008)

Inasawa, A., Ninomiya, C. and Asai, M., Suppression of tonal trailing-edge noise from an airfoil using a plasma actuator , AIAA Journal, Vol. 51, No. 7 (2013), pp.1695-1702.

Jukes, T., Segawa, T., Walker, S., Furutani, H., Iki, N. and Takekawa, S., Active separation control over a NACA0024 by DBD plasma actuator and FBG sensor, Journal of Fluid Science and Technology, Vol.7, No.1 (2012) pp.39-52.

Kaneda, I., Sekimoto, S., Nonomura, T., Asada, K., Oyama, A. and Fujii, K., An effective three-dimensional layout of actuation body force for separation control, International Journal of Aerospace Engineering, Article ID 786960 (2012), pp.1-12.

Kim, J. and Moin, P., Application of a fractional-step method to incompressible Navier-Stokes equations, Journal of Computational Physics, Vol.59, No.2 (1985), pp. 308-323.

Lilly, D. K., A proposed modification of the Germano subgrid-scale closure method, Physics of Fluids, A, Vol.4, No.3 (1992), pp.633-635.

Parker, R., Resonance effects in wake shedding from parallel plates: Some experimental observations, Journal of Sound and Vibration, Vol.4, No.1 (1966), pp.62-72.

Parker, R., Resonance effects in wake shedding from parallel plates: Calculation of resonant frequencies, Journal of Sound and Vibration, Vol.5, No.2 (1967), pp.330-343.

Rogers, C. B. and Parekh, D. E., Mixing enhancement by and noise characteristics of streamwise vortices in an air jet, AIAA Journal, Vol.32, No.3 (1994), pp.464-471.

Roth, J. R. and Dai, X., Optimization of the aerodynamic plasma actuator as an electrohydrodynamic (EHD) electrical device, Proceedings of 44th AIAA Aerospace Sciences Meeting and Exhibit, Aerospace Sciences Meetings (2006), Paper No.AIAA Paper 2006-1203.

Smagorinsky, J., General circulation experiments with the primitive equations, Monthly Weather Review, Vol.91 (1963), pp.99-164.

Schlichting, H., Boundary layer theory, 6th ed. (1968), p.641, McGraw-Hill.

Suzen, Y. B., Huang, P. G., Jacob, J. D. and Ashpis, D. E., Numerical simulations of plasma based flow control applications, Proceedings of the 35th Fluid Dynamics Conference and Exhibit (2005), Paper No. AIAA 2005-4633.

Thomas, F. O., Kozlov, A. and Corke, T. C., Plasma actuator for cylinder flow control and noise reduction, AIAA Journal, Vol. 46, No. 8 (2008), pp.1921-1931.

Yokokawa, Y. and Fukunishi, Y., Reduction of aerodynamic noise generated at the cavity by active flow control using thin ceramic actuator pieces, Theoretical and Applied Mechanics, Vol.50 (2001), pp.281-287.

Yokoyama, H. and Kato, C., Fluid-acoustic interactions in self-sustained oscillations in turbulent cavity flows, Physics of Fluids, Vol.21, No.10 (2009), pp.105103-1-105013-13 (2009).

Yokoyama, H., Kitamiya, K. and Iida, A., Flows around a cascade of flat plates with acoustics resonance, Physics of Fluids, Vol.25, No.10 (2013), pp.106104-1-106104-22. 